\title{
PASSIVE PROTECTION BY HUMAN SERUM IN MICE INFECTED WITH ENCAPSULATED STAPHYLOCOCCUS AUREUS
}

\author{
K. Yoshida, Y. Ichiman, S. Narikawa, M. Takahashi, E. Kono* and C. L. \\ San Clemente $\dagger$ \\ Department of Microbiology and *Department of Ophthalmology, St Marianna University \\ School of Medicine, Sugao, Takatu-ku, Kawasaki 213, and †Department of Microbiology and \\ Public Health, Michigan State University, East Lansing, Michigan, 48823, USA
}

Four serologically different capsular types have been identified among a large number of strains of Staphylococcus aureus (Yoshida, 1971, 1972a). Recently, we observed that approximately $85 \%$ of so-called unencapsulated strains of $S$. aureus could be shown to produce capsular antigen by the fluorescent-antibody technique (Harasawa et al., 1975), in most strains the antigen(s) being of capsule type A or B or both. Human sera often contain protective antibody to the Smith diffuse strain of $S$. aureus (Fisher, 1961), and a study was therefore made to elucidate the nature of these antibodies.

\section{MATERIALS AND METHODS}

Strains. Two strains of $S$. aureus were used: Smith diffuse and NS58D, representative of capsular types A and B respectively (Yoshida, 1971, 1972a).

Animals. The DD strain of conventional mice was used (Nihon Clea Co. Ltd, Tokyo), each weighing approximately $17 \mathrm{~g}$.

Human sera. One hundred samples of human sera were randomly selected from those received by the Clinical Laboratory, St Marianna University Hospital, Kawasaki.

Relative passive protective activities of human sera in mice challenged with strains of $S$. aureus. The passive protective activity of human sera in mice was examined by the procedure previously followed (Yoshida and Ekstedt, 1968; Yoshida et al., 1974; Yoshida, Ichiman and Ohtomo 1975). Human serum, $0.5 \mathrm{ml}$, was injected intraperitoneally into each of two groups of 10 mice. After 30 min., $0.5 \mathrm{ml}$ of a $5 \%$ mucin (Wilson-type) suspension containing $10^{5}$ colony-forming units (c.f.u.) of each S. aureus strain, Smith diffuse and NS58D, was injected intraperitoneally into the appropriate group of mice. The number of animals dying was recorded for one month after challenge. Human sera causing more than $80 \%$ survival were designated protective and those causing less than $60 \%$ survival were designated non-protective. Protective sera were also tested after dilution 1 in 3,1 in 10 and 1 in 30 with saline. The greatest dilution that protected mice against challenge was regarded as containing one unit of protective activity per $0.5 \mathrm{ml}$.

Treatment of serum with 2-mercaptoethanol. One $\mathrm{ml}$ of human serum, diluted to contain 4 units of protective activity, was treated with an equal volume of $0.2 \mathrm{M} 2$-mercaptoethanol and dialysed against $0.02 \mathrm{M}$ iodoacetic acid (Yoshida and Ekstedt, 1968). $0.5 \mathrm{ml}$ of the treated serum was used in the examination of its protective activity.

Treatment of serum with anti-immunoglobulin antibodies and absorption with Smith surface antigen. The serum used in these experiments was active in protection at a dilution of 1 in 30, that

Received 1 Aug. 1978; revised version accepted 19 Nov. 1978.

J. MED. MICROBIOL. - VOL. 12 (1979) 
is, $0.5 \mathrm{ml}$ contained 30 units of protective activity against challenge infection with the Smith diffuse strain, but there was no protection against the strain NS58D even when undiluted. To $0.5-\mathrm{ml}$ samples of this serum, diluted to contain 4 units of protective activity per $\mathrm{ml}$, was added $0.5 \mathrm{ml}$ of saline containing $0.3,0.15,0.07$ or $0.03 \mathrm{ml}$ of rabbit anti-human whole serum, or rabbit anti-human (IgG, IgA or IgM) serum (Hyland), or $1000,500,250,125$ or $62.5 \mu \mathrm{g}$ of Smith surface antigen (SSA) prepared by the method of Morse (1962). Additionally, 0.6 and $1.2 \mathrm{ml}$ of the anti-human sera were added to equal volumes of the human serum containing 4 units of protective activity per $\mathrm{ml}$. These mixtures were incubated at $37^{\circ} \mathrm{C}$ for $2 \mathrm{~h}$ and $0.5-\mathrm{ml}$ volumes of the supernatants, obtained after centrifugation at $6000 \mathrm{~g}$ for $15 \mathrm{~min}$., were injected intraperitoneally into a mouse, in groups of five. After $30 \mathrm{~min}$. the mice, and a control untreated group, were challenged with $10^{5}$ c.f.u. of Smith diffuse strain, and deaths were recorded for one month.

\section{RESULTS}

\section{Frequency of protective activity in human sera}

Of 100 human sera tested, 64 protected mice against challenge with $S$. aureus (table I). Of the 64 active sera, 60 protected against the Smith diffuse strain, 3 against strain NS58D, and one protected against both. Of the 60 sera that protected against challenge with the Smith diffuse strain, five were active at a dilution of 1 in 10 , and one was active at 1 in 30 and was considered to possess 30 units of protective activity per $0.5 \mathrm{ml}$. No serum sample was active at a dilution of 1 in 10 against strain NS58D.

\section{TABLE I}

Passive protection by 100 samples of human serum against subsequent challenge of mice with two encapsulated strains of Staphylococcus aureus

\begin{tabular}{l|cc}
\hline & \multicolumn{2}{|c}{$\begin{array}{c}\text { Number of sera found } \\
\text { protective }\end{array}$} \\
\cline { 2 - 3 } $\begin{array}{c}\text { Challenge strains and } \\
\text { (capsular type) }\end{array}$ & undiluted diluted 1 in 10 \\
\hline Smith diffuse (type A) & 60 & 5 \\
NS58D (type B) & 3 & 0 \\
Smith diffuse and NS58D & 1 & 0 \\
\hline
\end{tabular}

Treatment of protective human sera with rabbit anti-human immunoglobulin sera or 2-mercaptoethanol

The human serum protective against the Smith strain, diluted to contain 4 units of protective activity per $0.5 \mathrm{ml}$, was incubated with various volumes of rabbit anti-human immunoglobulin sera (anti-whole serum, anti-IgG, IgA or IgM), and the supernatant fluids obtained by centrifugation were examined for their protective effect as described in Methods. In these experiments (table II) each rabbit anti-human serum was found capable of removing the protective activity from the human serum, suggesting that each immunoglobulin class was associated with protection. Treatment with 2-mercaptoethanol also removed activity, indicating the importance of IgM antibody. 
TABLE II

Passive protection by a treated human serum* against subsequent challenge of mice with Smith diffuse strain of S. aureus.

\begin{tabular}{cl|c}
\hline $\begin{array}{c}\text { Amount (ml) of stated reagent } \\
\text { with which human serum was treated }\end{array}$ & Number of mice (dead/challenged) \\
\hline Rabbit anti-human IgG & $0 \cdot 6$ & $5 / 5$ \\
& $0 \cdot 3$ & $5 / 5$ \\
& $0 \cdot 15$ & $2 / 5$ \\
& $0 \cdot 07$ & $0 / 5$ \\
Rabbit anti-human IgA & $1 \cdot 2$ & $5 / 5$ \\
& $0 \cdot 6$ & $2 / 5$ \\
& $0 \cdot 3$ & $1 / 5$ \\
Rabbit anti-human IgM & $0 \cdot 15$ & $0 / 5$ \\
& $1 \cdot 2$ & $3 / 5$ \\
& $0 \cdot 6$ & $2 / 5$ \\
Rabbit anti-human serum & $0 \cdot 3$ & $1 / 5$ \\
& $0 \cdot 15$ & $0 / 5$ \\
& $0 \cdot 6$ & $5 / 5$ \\
& $0 \cdot 15$ & $5 / 5$ \\
2-Mercaptoethanol & $0 \cdot 07$ & $3 / 5$ \\
None (control) & $0 \cdot 03$ & $1 / 5$ \\
& $1 \cdot 0$ & $0 / 5$ \\
& & $5 / 5$ \\
& & $0 / 5$ \\
\hline
\end{tabular}

* See Methods.

\section{Absorption of protective sera by Smith surface antigen}

The protective effect of human serum against the Smith strain could be completely removed by absorption with SSA (table III). In this experiment, $500 \mu \mathrm{g}$ of the SSA was the smallest amount that completely removed activity from $0.5 \mathrm{ml}$ of a dilution of the serum containing, before absorption, 4 units of activity per $\mathrm{ml}$.

The concentrations of $\operatorname{IgG}, \operatorname{IgA}$ and $\operatorname{IgM}$ were measured in a protective serum $(\mathrm{m})$ and a non-protective serum (n) before and after absorption with $500 \mu \mathrm{g}$ of SSA. The results (table IV) suggest that the protective serum

\section{TABLE III}

Passive protection by $S S A^{*}$-absorbed human serum against subsequent challenge of mice with Smith diffuse strain of $S$. aureus.

\begin{tabular}{c|c}
\hline $\begin{array}{c}\text { Amount of SSA }(\mu \mathrm{g}) \text { with which } \\
\text { human serum was absorbed }\end{array}$ & $\begin{array}{c}\text { Number of mice } \\
\text { (dead/challenged) }\end{array}$ \\
\hline 62.5 & $0 / 5$ \\
125 & $1 / 5$ \\
250 & $3 / 5$ \\
500 & $5 / 5$ \\
1000 & $5 / 5$ \\
\hline
\end{tabular}

* Smith surface antigen. 
TABLE IV

Concentration of immunoglobulin in two human sera before and after absorption with Smith surface antigen

\begin{tabular}{|c|c|c|c|c|c|c|}
\hline \multirow[b]{2}{*}{$\begin{array}{c}\text { Class of } \\
\text { immunoglobulin }\end{array}$} & \multirow[b]{2}{*}{$\underset{\text { specimen }}{\text { Serum }}$} & \multirow{2}{*}{$\begin{array}{c}\text { Passive } \\
\text { protective } \\
\text { effect }\end{array}$} & \multicolumn{4}{|c|}{ Concentration of immunoglobulin $(\mathrm{mg} / 100 \mathrm{ml})$} \\
\hline & & & Initially & $\begin{array}{l}\text { After absorption } \\
\text { with } 500 \mu \mathrm{g} \text { of SSA }\end{array}$ & Difference & $\begin{array}{l}\text { Percent } \\
\text { reduction }\end{array}$ \\
\hline $\mathrm{IgG}$ & $\begin{array}{l}\mathrm{m} \\
\mathrm{n}\end{array}$ & $\begin{array}{l}+ \\
-\end{array}$ & $\begin{array}{l}1860 \\
2200\end{array}$ & $\begin{array}{l}1740 \\
2180\end{array}$ & $\begin{array}{r}120 \\
20\end{array}$ & $\begin{array}{l}6.5 \\
0.9\end{array}$ \\
\hline IgA & $\underset{\mathbf{n}}{\mathrm{m}}$ & + & $\begin{array}{l}372 \\
400\end{array}$ & $\begin{array}{l}352 \\
392\end{array}$ & $\begin{array}{r}20 \\
8\end{array}$ & $\begin{array}{l}5 \cdot 4 \\
2 \cdot 0\end{array}$ \\
\hline IgM & $\begin{array}{c}\mathrm{m} \\
\mathrm{n}\end{array}$ & $\begin{array}{l}+ \\
-\end{array}$ & $\begin{array}{l}172 \\
154\end{array}$ & $\begin{array}{l}158 \\
150\end{array}$ & $\begin{array}{r}14 \\
4\end{array}$ & $\begin{array}{l}8 \cdot 1 \\
2 \cdot 6\end{array}$ \\
\hline
\end{tabular}

contained more specific anti-SSA antibody than the non-protective serum: 7-fold more IgG, 2-7-fold more IgA, and 3-fold more IgM antibody. The protective serum therefore contained antibody to SSA in the three immunoglobulin classes.

\section{DisCUSSION}

Rogers (1962) and Koenig, Melly and Rogers (1962) suggested that some strains of $S$. aureus growing in the tissues of infected animals elaborate an anti-phagocytic surface antigen similar to the "Smith surface antigen" described by Morse (1962), but lost this capacity when cultured in artificial media. Fisher (1961) reported the frequent occurrence in human serum of antibody that passively protected mice against a fatal challenge dose of Smith diffuse strain; of 100 human sera tested 53 were protective. Fisher further showed that absorption of the human sera with heat killed Smith diffuse organisms removed the mouse protective antibody. The occurence of serologically distinct capsular types was demonstrated by Yoshida $(1971,1972 a)$ who found, by the serum-soft-agar technique, four serologically different capsular types among encapsulated strains of $S$. aureus, and that protection appeared to be capsular-type specific. Yoshida et al. (1975) later demonstrated that heatkilled compact-type strains of $S$. aureus induced protection in mice against a challenge with the Smith diffuse strain. Moreover, approximately $85 \%$ of the so-called "unencapsulated" strains of $S$. aureus were shown to produce capsular antigen and, by the fluorescent antibody technique, that $83 \%$ were of capsular type A or B or both (Harasawa et al., 1975). In the experiments reported here 64 out of 100 human sera passively protected mice later challenged with a fatal strain of capsular type A or B or both. Protective antibodies against a capsular type-A strain occurred 20 times more frequently than against a capsular type-B strain. Only one of the sera passively protected mice against challenge with both capsular types. Protective antibodies against capsular types C and D were not studied in these experiments because they have been found to occur too infrequently. 
Regarding the nature of protective antibody, Yoshida and Ekstedt (1968) and Ekstedt and Yoshida (1969) noted that in mice passive protective antibody against the Smith diffuse strain was associated with the IgM fraction of rabbit and mouse antisera. Recently, Yocum et al. (1976) reported recurrent staphylococcal pyoderma in two patients with IgM deficiency, suggesting that protective antibody in human sera against $S$. aureus strains could be in the IgM fraction. In our experiments (table II) passive protective activity of human serum in mice was 2-mercaptoethanol sensitive and could also be removed by treatment with appropriate amounts of rabbit anti-IgG, anti-IgA or anti-IgM sera. Absorption of protective human sera with SSA (table IV) decreased the serum IgG, IgA and IgM content by $6.5 \%, 5.4 \%$ and $8.1 \%$ respectively. However, absorption of non-protective sera with SSA produced less fall in the IgG, IgA and IgM content than was the case with protective serum (table IV). This finding supports the view that IgM antibodies to the $S$. aureus capsular antigen play a part in protection (Ekstedt and Yoshida, 1969; Yocum et al., 1976; Yoshida, 1972b).

\section{SUMMARY}

The occurrence and nature of passive protective antibody in 100 samples of human serum was investigated in mice challenged with strains of Staphylococcus aureus capsular types A (Smith diffuse strain) and B (strain NS58D). Sixty of the sera passively protected mice against the capsular type-A strain, three against type $B$, and one against both types. Rabbit antisera against human IgG, IgA and IgM could remove the protective activity from a human serum of high potency, and the activity was also sensitive to 2-mercaptoethanol. Absorption with Smith surface antigen removed protective activity and reduced the concentration of IgG 7-fold, IgA 2.7 fold and of IgM 3-fold more than in a non-protective serum. Consequently, the protective activity of human serum is believed to be associated with antibodies to the $S$. aureus capsular antigen in the three immunoglobulin classes.

\section{REFERENCES}

EKSTEDT, R. D. AND YoshIDA, K. 1969. Immunity to staphylococcal infection in mice: effect of living versus killed vaccine, role of circulating antibody, and induction of protection-inducing antigen(s) in vitro. J. Bact., $100,745$.

FISHER, S. 1961. Observations on an anti-staphylococcal mouse protective antibody in human sera. Aust. J. exp. Biol. med. Sci., 39, 413.

Harasawa, I., Minegishi, Y., Ohtomo, T. AND Yoshida, K. 1975. Capsular typing of Staphylococcus aureus strains by the fluorescent antibody technique. Jap. J. clin. Path., 23, 469.

Koenig, M. G., Melly, M. A. AND Rogers, D. E. 1962. Factors relating to the virulence of staphylococcus. II. Observations on four mouse-pathogenic strains. J.exp. Med., 116, 589.

MORSE, S. I. 1962. Isolation and properties of a surface antigen of Staphylococcus aureus. J. exp. Med., 115, 295.

RoGERS, D. E. 1962. Staphylococci and man. J. Am. med. Ass., 181, 38.

Yocum, M. W., Strong, D. M., Chusid, M. J. AND LaKIN, J. D. 1976. Selective immunoglobulin 
M (IgM) deficiency in two immunodeficient adults with recurrent staphylococcal pyoderma. Am. J. Med., 60, 486.

YoshidA, K. 1971. Demonstration of serologically different capsular types among strains of Staphylococcus aureus by the serum-soft agar technique. Infect. Immun., 3, 535.

YosHIDA, K. 1972a. Isolation of an additional capsular-type strain of Staphylococcus aureus by the serum-soft agar technique. Infect. Immun., 5, 833 .

Yoshida, K. 1972b. Relation of protection inducing activity in mice to capsular type of strains of Staphylococcus aureus. Jap. J. Bacteriol., 27, 829 (in Japanese).

Yoshida, K. AND EKSTEDT, R. D. 1968. Antibody response to Staphylococcus aureus in rabbits: sequence of immunoglobulin synthesis and its correlation with passive protection in mice. $J$. Bact., 96, 1540.

Yoshida, K., Ichiman, Y. AND OHтомo, T. 1975. Induction of resistance with heat-killed compact-type strains of Staphylococcus aureus against challenge with the diffuse variant of the Smith strain of Staphylococcus aureus. Infect. Immun., 12, 939.

Yoshida, K., Nakamura, A., Ohtomo, T. AND Iwami, S. 1974. Detection of capsular antigen production in unencapsulated strains of Staphylococcus aureus. Infect. Immun., 9, 620. 